The Journal of International Lingual, Social and Educational Sciences Year: 2019, Volume: 5, Number: 1

DOI:1034137/jilses.481548

Geliş Tarihi:12.11.2018

Received:12.11.2018

Kabul Tarihi:10.07.2019

Accepted:10.07.2019

Makale Türü: Araştırma Makalesi

Research Type: Research Article

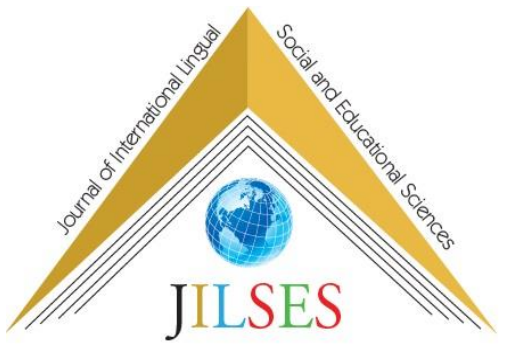

\title{
8. Sınıf "Enerji Kaynakları ve Geri Dönüşüm” Konusu Öğretiminde Jigsaw Tekniğinin Etkileri $^{1}$
}

\author{
Evşen Aymen Peker² Mübeccel Yalçın ${ }^{3}$
}

\section{Özet}

Bu çalışmanın amacı fen bilimleri öğretim programında yer alan “enerji kaynakları ve geri dönüşüm” konusunun öğretiminde, jigsaw tekniği kullanılmasının ögrencilerin akademik başarlları ve fene yönelik tutumlarına etkisini incelemektir. Çalışmada nicel araştırma yöntemlerinden eşitlenmemiş gruplara ön test-son test uygulamasına dayalı yarı deneysel desen kullanılmıştır. Araştırmanın örneklemi 8. Sinıfta ögrenim gören toplam 70 ögrenciden (28 kı-42 erkek) oluşmaktadır Araştırmada veri toplama aracı olarak Akademik Başarı Testi, Fen Bilimlerine Yönelik Tutum Ölçeği ve Fen Öğrenme Yaklaşımlarına Yönelik Tutum Ölçeği kullanılmıştır. Veriler, MANCOVA ve ANCOVA teknikleri ile analiz edilmiştir. Araştırmanın sonucunda; jigsaw tekniğini içeren tasarımın öğrencilerin akademik başarılarını olumlu yönde etkilediğ $i$, fen bilimleri dersi ve fen ögrenme yaklaşımlarına yönelik tutum son testleri üzerinde ise anlamlı bir etkisi olmadı̆̆ belirlenmiştir.

Anahtar Kelimeler: İşbirlikli öğrenme, jigsaw tekniği, enerji kaynaklarl, tutum

\section{The Effects of Jigsaw Technique on Teaching of "Energy Resources and Recycle" Subject in $8^{\text {th }}$ Class}

\begin{abstract}
The aim of this study is to investigate the effect of using jigsaw technique on teaching of "Energy Source and Recycle" which is included in science curriculum, on the students' academic achievements and attitudes towards science lesson. In the study, semi-experimental design which is one of the quantitative research methods and which is based on pre-test-post-test application for unequal groups was used. The sample of the study consisted of 70 students (28 girls and 42 boys) studying in the 8th grade. The data collection instruments which were used in the study is Academic Achievement Test, Attitude towards Physical Sciences Scale, Attitude towards Science Learning Approach. The data were analyzed with MANCOVA and ANCOVA techniques. As a result of the research; It was determined that jigsaw technique had a positive effect on students' academic achievement and that did not have a significant effect on the post-test of science course and attitude towards science learning approaches.
\end{abstract}

Key Words: cooperative learning, jigsaw technique, energy source and recycle, attitude

\footnotetext{
${ }^{1} \mathrm{Bu}$ makale 5. Asos Uluslararası Eğitim Bilimleri Sempozyumunda sunulan sözlü bildirinin genişletilmiş versiyonudur.

${ }^{2}$ Dr., MEB, Tevfik İleri İHO, evsenaymen@hotmail.com, https://orcid.org/0000-0003-0969-5753

${ }^{3}$ Dr., MEB, Altınkum MTAL, mubecce182@ hotmail.com, https://orcid.org/0000-0002-2941-6611
} 


\section{Giriş}

Dünya nüfusundaki hızlı artış, sanayileşme, yaşanan teknolojik gelişmeler ve artan tüketim ihtiyacı yoğun bir enerji gereksinimine neden olmaktadır. Toplumun refahı ve insanlığın gelişimi için gerekli olan bu ihtiyacın karşılanması, ülkeleri temin kaynaklarını çoğaltmaya ve fosil yakıtlara bağımlılığı azaltmaya yönlendirmiştir. Çünkü temel enerji kaynaklarından olan petrol ve doğalgaz gibi enerji kaynaklarının rezervi hızla tükenmekte, fiyatlarındaki ani değişimler tutarsızlık yaratmakta ve bu tür yakıtların kullanılması sonucu ortaya çıkan karbondioksit ve benzeri sera gazları küresel iklim değişikliğine neden olmaktadır. Tüm bu nedenler bilim insanlarını alternatif enerji kaynakları bulmaya yöneltmiş ve yenilenebilir enerji kaynaklarının kullanımı özendirilmeye ve teşvik edilmeye başlanmıştır. Enerji tüketiminde yenilenebilir kaynakların kullanılması ile ekonomik büyüme arasındaki pozitif bir ilişki olduğu ve bu kaynakların etkili bir tüketim faktörü olduğu yapılan araştırmalarda görülmüştür (Bayraç ve Çıldır, 2017; Çınar ve Yılmazer, 2015).

Kullanılışlarına göre enerji kaynakları yenilenemez ve yenilenebilir kaynaklar olmak üzere iki grupta incelenmektedir. Milyonlarca yıl önce yaşayan bitki ve hayvanların yer altında kalan fosillerinden elde edilen kömür, petrol, doğalgaz ve nükleer enerji gibi tükenebilir kaynaklara yenilenemez enerji kaynakları denilmektedir (Koç ve Şenel, 2013). Yenilenebilir enerji ise; enerji kaynaklarının stoklarında herhangi bir azalma olmadan üretimine ve tüketimine devam edilebilen (Aydın, 2014), insan ömrüne kıyasla daha kısa sürede yerine konulabilen (MEB, 2014), güneş, rüzgar, hidroelektrik ve biokütle başta olmak üzere gelgit, dalga ya da jeotermal enerji kaynaklarından elde edilen enerji olarak tanımlanmaktadır (Koç ve Şenel, 2013; Verbruggen ve diğerleri, 2010).

Yenilenebilir kaynaklardan enerji elde etmek sürdürülebilir kalkınmanın devamlılığı, çevreye verilen zararın en aza indirilmesi ve ekolojik dengenin korunması için gerekli hale gelmiştir (Gezer, 2013). Yenilenebilir kaynaklardan elde edilen enerji, yerli kaynakların kullanımına dayandığından ülkenin konumu bu aşamada önemli rol oynar. Ülkemizin güneş, rüzgar ve hidroelektrik enerji potansiyeli düşünüldügünde, yenilenebilir enerji kaynaklarını kullanmanın enerji ihtiyacımızı karşılamada dışa bağımlılığımızı azaltacağı görülür.

Yenilenebilir enerji kaynaklarının günümüz ve gelecek için önemi göz önüne alındığında, toplumun bilinçlendirilmesi, yenilenebilir enerji kaynaklarının kullanımının özendirilmesi ve artırılmasında eğitim büyük öneme sahiptir. Politik görüşlerin yanı sıra toplumun tercih ve tutumları yenilenebilir enerji kaynaklarının daha geniş sahalarda kullanılmasını sağlayacaktır (Lars ve Aadu, 1988). Bu nedenle, okul öncesi dönemden başlamak üzere tüm bireylerin bu konuda farkındalıklarının artırılması gerekir. Keser, Özmen ve Akdeniz'e (2003) göre hem gelişmiş hem de gelişmekte olan ülkelerde enerji eğitimi son 20 yılda yeni bir disiplin olarak görülmektedir. Son yıllarda yenilenebilir enerji hakkında birçok araştırma yapılmaktadır. Kılıçaslan, Aymen Peker ve Gün (2011) ilköğretim 6-7 ve 8. sınıf öğrencilerinin yenilenebilir enerji kaynaklarının çevreye olan katkısına ilişkin görüşlerini değerlendirdikleri çalışmalarında, öğrencilerin yenilenebilir enerji kaynakları konusunda eksik bilgiye sahip olduklarını belirlemiştir. Çakırlar (2015) ise ortaöğretim öğrencilerinin yenilenebilir enerji kaynakları konusundaki farkındalık düzeylerini belirlemeyi amaçladığı çalışmasında, ortaöğretim öğrencilerinin yenilenebilir enerji kaynaklarına yönelik bilgi düzeylerinin çok düşük olduğunu ve öğrencilerin bu kaynaklara ilişkin örnekler vermede zorlandıklarını tespit etmiştir.

Çocuğun içtiği suyun, yediği yemeğin, soluduğu havanın kısacası yaşadığı dünyanın çekici ve şaşırtıcı zenginliğinin eğitimi şeklinde tanımlanan fen eğitimi (Gürdal, 1988), bilim ve teknoloji ile ilgili sosyo-bilimsel problemlerin çözümüne yönelik bilimsel ve ahlaki akıl yürütme becerilerini de kapsamaktadır. Ülkemizde uygulanmakta olan fen bilimleri öğretim programında, birey, çevre ve toplum arasındaki karşılıklı etkileşimi fark ettirmek; toplum, ekonomi ve doğal kaynaklara ilişkin sürdürülebilir kalkınma bilincini geliştirmek ve sosyo bilimsel konuları kullanarak muhakeme yeteneği, bilimsel düşünme alışkanlıkları ve karar verme becerileri geliştirmek gibi özel amaçlar yer almaktadır. Yenilenebilir enerji kaynaklarının öğretimi bu alt amaçlarla ilişkilidir. 6. sınıf seviyesinde "madde ve ısı" ünitesinde "yakıtlar" başlığında ve 8. sınıf seviyesinde "canlılar ve enerji ilişkileri” ünitesinde "enerji kaynakları ve geri dönüşüm” başlı̆̆ında yenilenebilir enerji kaynakları konusunun ele alındığı görülmektedir. Yenilenebilir kaynakların kullanılması aynı zamanda gelecek nesiller ve gezegenimizin devamlılığı konusunda bireylerin sorumluluk almasını gerektirmektedir (MEB, 2013; MEB, 2018). Ülkemizde yürütülmekte olan fen bilimleri öğretim programı pek çok basamak ve öğrenme alanında yenilenebilir enerji konusuna değinmiştir.

Amacı "tüm öğrencileri fen okuryazarı bireyler olarak yetiştirmek" şeklinde ifade edilen fen bilimleri öğretim programında, öğrencileri merkeze alan, öğretim etkinliklerine öğrencilerin aktif olarak katılmalarını hedefleyen, araştırma-sorgulamaya dayalı öğrenme yaklaşımı temel alınmıştır. Öğrencilerin işbirliğine açık, sürdürülebilir 
kalkınma bilinciyle yaşam boyu öğrenen, akranları ile birlikte bir bilgiyi araştırı sorgularken etkili iletişim kurabilen bireyler olarak yetiştirilmesi amaçlanmaktadır. Aynı zamanda programda iş birliğine dayalı öğrenme ortamlarına özellikle vurgu yapılmıştır (MEB, 2013; MEB, 2018). İşbirlikli öğrenme yöntemi öğrencilerin öğrenme sürecinde aktif rol aldıkları, öğretmenlerin ise rehber konumda olduğu bir aktif öğrenme yöntemidir ve geleneksel yönteme bir alternatif olarak önerilmektedir (Gillies ve Boyle, 2010; Surian ve Damini; 2014).

Genel olarak işbirlikli öğrenme yöntemi farklı öğrenme stilleri, yetenekleri, ilgi ve algıları olan öğrencilerden heterojen gruplar oluşturarak başlatılır. Öğrenciler akademik bir konuda ortak amaç doğrultusunda çalışmalar yapar. Birbirlerine yaptıkları çalışmaları anlatarak etkileşimde bulunur ve birbirlerinin öğrenmesinden sorumludur (Akar ve Doymuş, 2015; Senemoğlu, 2004). Öğrencilerin işbirlikli öğrenme ortamlarında yaparak yaşayarak fen etkinliklerine katılmaları ve bir grup içinde çalışmaları öğrenmeyi olumlu etkilemektedir (Bilgin ve Karaduman, 2005). Yapılan pek çok çalışmada iş birliğinin öğrencilerin akademik başarı, motivasyon, tutum, kalıcılık, üst düzey düşünme becerilerini olumlu etkilediği vurgulanmaktadır (Açıkgöz Ün, 2008; Doymuş ve Şimşek, 2007). İşbirlikli öğrenme yöntemi öğrencilerin problem çözme ve eleştirel düşünme gibi bilimsel süreç becerileri ile yeteneklerini geliştiren, üst düzey akademik ve sosyal beceri kazandıran, öğrenciye öğrenme sorumluluğu vererek araştırma ve derse devam zorunluluğunu artıran bir yöntemdir (Mark, Volk ve Hinckley ,1991; Carpenter, 2003; Akar ve Doymuş, 2015).

Literatür incelendiğinde pek çok işbirlikli öğrenme yönteminden bahsedildiği görülmektedir. Birlikte öğrenme, öğrenci takımları, grup araştırması, birlikte soralım birlikte öğrenelim, birleştirme(jigsaw) teknikleri işbirlikli öğrenme yöntemine dayalı olarak geliştirilen tekniklerdir (Açıkgöz Ün, 2008; Akınoğlu, 2007; Doymuş ve Doğan, 2013). Jigsaw tekniği, dilimize birleştirme olarak çevrilmiş olup, genel olarak öğrenciler arasındaki iş birliğini ilerletmeyi ve rekabet ortamını kaldırarak öğrencilerin birbiriyle iletişim kurmalarını sağlamayı amaçlamaktadır (Ghaith ve El-Malak, 2004; Zacharia, Xenofontes ve Manoli, 2010). Bu teknikle öğrenciler, akademik bir bulmacanın parçalarını öğrenerek, bu parçaları birleştirme ve bir bütün haline getirme yoluyla bilgi edinirler (Aronson ve Patnoe, 1997). Jigsaw tekniği, öğrenciler arasındaki iş birliğini ilerletmeyi ve rekabet ortamını kaldırarak öğrencilerin birbiriyle iletişim kurmalarını sağlamayı amaçlamaktadır (Ghaith ve El-Malak, 2004; Zacharia, Xenofontes ve Manoli, 2010). Bu teknikte her öğrenci öğrenme materyalinin küçük bir bölümünden sorumludur ve öğrendiklerini diğer üyelere öğretmesi gerekir. Başkalarına öğretmek öğrencilerin yeni öğrendiği bilgilerle ön bilgilerini ilişkilendirme yeteneğini geliştirerek bilgiyi yeniden yapılandırmalarına imkân verir (Tran, 2016). Bu teknikle öğrenciler bilgileri kendine özgü düzenler ve arkadaşları için açıklamalar hazırlar (Souvignier ve Kronenberger, 2007). Öğrencilerin grubun hedefleri nedeniyle bireysel sorumluluk almasını sağlamak bu teknikten olumlu sonuçlar elde edilmesini sağlar (Moreno, 2009). Öğrenciler arasındaki rekabet ortamını kaldırarak yardımlaşma ve birlikte öğrenmeyi sağlayan tekniğin öğrencilerin kendi öğrenmeleri üzerinde olumlu tutumlar oluşturduğu ifade edilmektedir. Jigsaw ile öğrenciler arasında olumlu etkileşimler gerçekleşir, öğrencilerin özgüveni ve öğrenme motivasyonu artar (Slavin, 2014).

İlk olarak 1978'de Elliot Aronson tarafından geliştirilen teknik konusunda, geçen otuz yıl içerisinde farklı bilim insanları değişiklikler yapmış, günümüzde altı farklı Jigsaw tekniğinin kullanımı söz konusu olmuştur. Bunlar Aronson tarafından 1978 yılında geliştirilen Jigsaw I; Slavin'in 1987 yılında geliştirdiği Jigsaw II, Stahl tarafından 1994 yılında geliştirilmiş olan Jigsaw III, Holliday tarafindan 2000 yılında geliştirilen Jigsaw IV, Heeden tarafindan geliştirilen Ters Jigsaw (2003) ve Doymuş (2007) tarafindan geliştirilen Konu Jigsaw'ı şeklindedir. Teknikler arasında uygulamada kullanılan ara sınavlar ve formlar gibi farklılıklar olmasına rağmen, genel olarak Jigsaw uygulanırken izlenecek aşamalar giriş, materyalin bölünmesi, uzman gruplar ve uzman grupların asıl gruplara dönüşü olarak sıralanabilir (Açıkgöz Ün, 2008; De Paz, 2001; Doymuş ve Doğan, 2013; Heeden, 2003; Kılıç, 2013; Şimşek, 2007). Uygulama aşamaları aşağıda ayrıntılı olarak açıklanmıştır.

Giriș: Bu aşamada öğretmen sınıfı heterojen gruplara ayırır. Gruplar oluşturulurken cinsiyet, yetenek ve kişilik özellikleri bakımından karma gruplar olmasına ve gruptaki kişi sayısının 3-7 kişi arasında olmasına özen gösterilir. Kalabalık gruplardan kaçınılmalıdır.

Materyalin Bölünmesi: Öğrenilecek olan ünite ya da konu her bir gruptaki öğrenci sayısı kadar küçük parçaya ayrılır. Öğretmen bu materyali tanıtarak, ne öğrenileceği, nasıl çalışılması gerektiği, değerlendirme yöntemlerini öğrencilere anlatır ve her öğrencinin bir parçayı seçmesi sağlanır ya da öğretmen parçaları dağıtır.

Uzman Gruplar: Jigsaw tekniği için geçerli bir aşamadır. Öğretmen temel gruplardaki aynı bölümü seçen öğrenciler ayrı bir gruba toplar ve bu gruba "uzman grup" adı verilir. Uzman grubunda yer alan öğrenciler kendi konularıyla ilgili araştırma yapar, tartışır, soru sorup öğrenir, konu hakkındaki düşüncelerini paylaşırlar. Öğretmen 
grupların işbirlikli çalışmasına ve yardımlaşmalarına rehberlik eder. Uzan gruptaki bu öğrenciler temel gruplarına döndüklerinde konunun bu parçasını arkadaşlarına nasıl anlatacaklarını tasarlar ve rapor oluştururlar.

Uzman Grupların Asll Gruplara Dönüsü: Uzman grubundan ayrılan öğrenciler, temel gruplarına dönerek materyalin kendi sorumluluklarındaki bölümünü hazırladıkları rapor doğrultusunda arkadaşlarına anlatırlar. Burada uzmanların görevi diğer arkadaşların öğrenmesini sağlamaktır. Bu nedenle konuyu açıklar, sorulara cevap verir ve tartışırlar. Son olarak tamamlama aşamasında öğrencilere tüm sınıfın katıldığı bir etkinlik yaptıılır. Temel gruplara bir sunu hazırlatarak ya da bireysel sunumlar yapmaları sağlanarak öğrenmeleri bütünleştirilir. Değerlendirme yapılarak teknik tamamlanır.

Bu çalışmada kullanılan Jigsaw I tekniği giriş, materyalin bölünmesi, uzman gruplar ve uzman grupların asıl gruplara dönüşü olmak üzere yukarıda açıklanan standart aşamalardan oluşur. Jigsaw II tekniğinde yer alan bireysel değerlendirme ve puanlama, Jigsaw III tekniğinde yer alan süreçleri incelemek için kullanılan formlar, Jigsaw IV tekniğinde yer alan quizler, Jigsaw I tekniğinde yer almaz. Çalışmada öğrencilerin Jigsaw I tekniği ile enerji kaynakları ve geri dönüşüm konusunu öğrenmeleri sağlanmıştır. Öğrencilerin ön bilgilerini belirlemek amacıyla hazırlanan son test, Jigsaw I tekniğinin son aşamasında yer alan değerlendirme için tekrarlanmıştır. Jigsaw I tekniğinin bu çalışmanın örneklemine nasıl uygulandığı, yöntem bölümünde ayrıntılı olarak anlatılmıştır.

Literatür incelendiğinde, jigsaw tekniklerini kullanarak yapılan pek çok çalışmada, tekniğin akademik başarı üzerindeki etkisinin incelendiği görülmektedir. Özellikle fen konularının öğretiminde yapılan çalışmalar incelendiğinde; jigsaw tekniği ile yapılan öğretimde öğrencilerin akademik başarılarında Jigsaw tekniği kullanıldığında olumlu şekilde anlamlı bir artış olduğu belirlenmiştir. (Atasoy, Genç, Kadayıfçı ve Akkuş, 2007; Doymuş ve Şimşek, 2007; Eliks, 2005; Sancı, 2011; Tran ve Lewis, 2012; Uçar, 2014). Berger ve Hazne (2005), jigsaw tekniğini kullanarak yaptıkları çalışmalarında işbirlikli öğrenen grubun bilimsel süreç becerilerini daha etkin kullandıklarını ve daha yüksek güdülenme ile konuyla daha fazla ilgilendiklerini belirlemişlerdir. Dori, Yeroslavski ve Lazorowits (1995), hücre konusunun öğretiminde jigsaw tekniği ile yürütülen uygulamanın öğrencilerin akademik başarısının yanı sıra öğretim etkinliğine yönelik tutumlarının olumlu etkilendiğini ifade etmişlerdir. Tamah (2007), jigsaw tekniğinin öğrencilerin sınıf içi etkileşimlerini olumlu yönde etkilediğini ve tartışma ortamları oluş̧urmada olumlu etkisi olduğunu, Doğru ve Ünlü (2012), öğrencilerin motivasyonlarının yükseldiği ve fen kaygılarının azaldığını saptamışıtı. Altıparmak ve Nakiboğlu (2015) Jigsaw-I tekniğinin deney yapma, deney sonuçlarını yorumlama gibi sosyal ve bilimsel becerileri geliştirdiğini ifade etmişlerdir. Ayrıca Jigsaw tekniği kullanılarak yürütülen derslerde öğrencilerin fene ve sınıf içi etkileşimle öğretime katılmaya yönelik tutumlarında olumlu değişimler gözlemlendiğini belirten çalışmalar da mevcuttur (Demirtaş, 2008; De Paz, 2001; Köse, Ergü ve Gezer, 2010; Student, 2015; Tran ve Lewis, 2012;).

Öğrenme ortamında farklı yöntem ve teknikler kullanmanın öğrenme çıktıları üzerinde farklı etkiler oluşturmasından hareketle, fen bilimleri dersinde 8 . sınıf "canlılar ve enerji ilişkileri” ünitesinde yer alan "enerji kaynakları ve geri dönüşüm" konusunun öğretiminde jigsaw tekniğinden faydalanılmıştır. Çalışmanın amacı; yenilenebilir enerji kaynakları konusunun öğretiminde jigsaw tekniğinden yararlanmanın öğrencilerin akademik başarısı ve fen tutumlarına etkisini araştırmaktır.

\section{Yöntem}

Çalışmada nicel araştırma yöntemlerinden eşitlenmemiş gruplara ön test-son test uygulamasına dayalı yarı deneysel desen kullanılmıştır. Tüm değişkenleri kontrol altına almanın mümkün olmadığı durumlarda uygulama geçerliği yüksek bir model olarak en çok uygulanan yarı deneysel araştırma deseninde (Cohen, Manion ve Marrison, 2007), araştırmacı var olan gruplarda farklı koşulları inceler (Plano Clark ve Creswell, 2015). Eşitlenmemiş kontrol gruplu yarı deneysel desenlerde grupların yansız atama yoluyla belirlenmeleri için özel bir çaba harcanmaz. Grupların olabildiğince benzer nitelikte olmasına özen gösterilir ve grupların hangisinin kontrol hangisinin deney grubu olacağına yansız atama yoluyla karar verilir (Karasar, 2011). Araştırmada kullanılan ölçme araçlarından elde edilen veriler istatistiksel olarak analiz edilerek örneklemden toplanan veriler evrene genellendiği için nicel araştırma yöntemi, etkisi ölçülmek istenilen değişkenler örnekleme uygulanarak elde edilen verilerin karşılaştırmalı şekilde yorumlanması deneysel deseni, örneklem grubuna dahil edilen okulda çalışma yapılacak olan 8. sınıf şubelerinin okul yönetimi tarafindan önceden oluşturulmuş olması eşitlenmemiş gruplara ön test-son test uygulamasına dayalı yarı deneysel deseni kullanmayı gerekli kılmışıtır. Araştırma tasarımı Tablo 1 'de gösterilmiştir. 
Tablo 1.

Araştırmanın Tasarımı

\begin{tabular}{|c|c|c|c|c|}
\hline Grup & Grup Sembolü & Ön Test & Yöntem & Son Test \\
\hline $\mathrm{G}_{1}$ & $\mathrm{DG}$ & $\mathrm{O}_{1.1}$ & $\mathrm{X}$ & $\mathrm{O}_{1.2}$ \\
\hline $\mathrm{G}_{2}$ & $\mathrm{KG}$ & $\mathrm{O}_{2.1}$ & & $\mathrm{O}_{2.2}$ \\
\hline $\mathrm{G}_{1}$ & \multicolumn{4}{|c|}{ Deney Grubu (DG): Jigsaw Tekniğinin yer aldığı ders tasarımı uygulanan grup } \\
\hline $\mathrm{G}_{2}$ & \\
\hline $\mathrm{O}_{1.1,} \mathrm{O}_{2.1}$ & \multicolumn{4}{|c|}{$\begin{array}{l}\text { Kontrol ve Deney Grubu Ön Testler (Akademik Başarı Testi (ABT), Fen Öğrenme Yöntemlerine Yönelik Tutum Ölçeği } \\
\text { (FÖYyT), Fen Bilimlerine Yönelik Tutum Ölceği (FByT)) }\end{array}$} \\
\hline $\begin{array}{l}\mathrm{O}_{1.2,}, \mathrm{O}_{2.2} \\
\mathrm{X}\end{array}$ & \multicolumn{2}{|c|}{ Kontrol ve Deney Grubu Son Testler (ABT, FÖYyT, FByT). } & \multicolumn{2}{|c|}{ Jigsaw Tekniğinin yer aldığı ders tasarımının uygulanması. } \\
\hline
\end{tabular}

Çalışma gruplarının deney ve kontrol grubu olarak belirlenmesi yansız atama ile (random) gerçekleştirilmiş, her gruba eşzamanlı olarak Akademik Başarı Testi (ABT), Fen Öğrenme Yöntemlerine Yönelik Tutum Ölçeği (FÖYyT) ve Fen Bilimlerine Yönelik Tutum Ölçeği (FByT) uygulanmıştır. Deney grubu öğrencileri ile "Enerji Kaynaklarl ve Geri Dönüşüm” konusu öğretiminde jigsaw tekniğinden yararlanılırken, kontrol grubu öğrencileri ile konu öğretim programı ve öğretmen kılavuz kitabında yer alan etkinliklerle işlenmiştir. Her iki grupta da süreç araştırmacılar tarafından yürütülmüştür. Deneysel uygulama sonrasında yine her iki gruba eşzamanlı olarak ön test olarak uygulanan testlerin son testleri uygulanmıştır.

\section{Araştırmanın Çalışma Grubu}

Yarı deneysel desenler, düşük dış geçerliliğe sahip olduğu için, bu araştırmada evren ve örneklem seçilmeden çalışma grubu belirlenmiştir (Büyüköztürk, 2011). Çalışma, araştırmacılara uygulama kolaylığı sağlaması nedeniyle 2014-2015 Eğitim Öğretim yılında Samsun ili Atakum ilçesindeki bir ortaokulda gerçekleştirilmiştir. Çalışma yapılan gruplarda; 13-14 yaş aralığında sekizinci sınıf öğrencileri bulunmaktadır. İki grubun Fen Bilimleri dersine aynı öğretmen girmektedir. Çalışma grubu 70 sekizinci sınıf öğrencisinden oluşmaktadır. Yansız atama ile belirlenen kontrol ve deney grupları ile ilgili bilgiler Tablo 2Hata! Başvuru kaynağı bulunamadı.'de yer almaktadir.

Tablo 2.

Gruplarda Yer Alan Öğrencilere Ait Bilgiler

\begin{tabular}{lrrrrrr}
\hline \multirow{2}{*}{ Grup } & & $\underline{\mathbf{K}}$ & & $\underline{\text { Erkek }}$ & & \multicolumn{2}{c}{ Toplam } \\
\cline { 2 - 7 } & $\mathbf{f}$ & $\mathbf{\%}$ & $\mathbf{f}$ & $\mathbf{\%}$ & $\mathbf{f}$ & $\mathbf{\%}$ \\
\hline Deney (8E) & 18 & 25.71 & 19 & 27.14 & 37 & 52.85 \\
Kontrol (8F) & 10 & 14.29 & 23 & 32.85 & 33 & 47.14 \\
Toplam & 28 & 40.00 & 42 & 60.00 & 70 & 100 \\
\hline
\end{tabular}

Tablo 2Hata! Başvuru kaynağı bulunamadı. incelendiğinde kontrol ve deney grubundaki öğrenci sayılarının birbirine yakın olmasına rağmen cinsiyet açısından farklılık olduğu göze çarpmaktadır.

\section{Değişkenler}

Çalışmada üç bağımlı ve beş bağımsız değişken olmak üzere toplan 8 değişken bulunmaktadır. Değişkenlere ait bilgiler Tablo 3'de verilmiştir. 
Tablo 3.

Değişkenlere Ait Bilgiler

\begin{tabular}{cccc}
\hline Değişken Türü & Adı & Değişken & Veri Tipi \\
\hline Bağımlı & ABT-S & Sürekli & Aralıklı \\
Bağımlı & FÖYyT-S & Sürekli & Aralıklı \\
Bağımlı & FByT-S & Sürekli & Aralıklı \\
Bağımsız & Yöntem & Ayrık & Kategorik \\
Bağımsız & Cinsiyet & Ayrık & Kategorik \\
Bağımsız & ABT-Ö & Sürekli & Aralıklı \\
Bağımsız & FÖYyT-Ö & Sürekli & Aralıklı \\
Bağımsız & FByT-Ö & Sürekli & Aralıklı
\end{tabular}

\section{Ölçüm Araçları}

$\mathrm{Bu}$ çalışmada üç ölçüm aracı kullanılmıştır. Bu araçlar; öğrencilerin Canlılar ve Enerji İlişkileri ünitesinde yer alan Enerji Kaynakları ve Geri Dönüşüm konusu ile ilgili bilgilerini ölçmeye yönelik geliştirilen 25 soruluk başarı testi, öğrencilerin fen bilimleri dersi ve fen öğrenme yaklaşımları konusundaki tutumlarını belirlemeye yönelik Aymen Peker (2018) tarafindan geliştirilen üç faktörlü 15 maddelik Fen Bilimleri Dersine Yönelik Tutum Ölçeği (KMO değeri .92, Barlett testi anlamlılık değeri .00 ve Cronbach güvenirlik katsayısı 0.89) ve üç faktörlü 10 maddelik Fen öğrenme yaklaşımına yönelik tutum ölçeğidir (KMO değeri .88, Barlett testi anlamlılık değeri .00 ve Cronbach güvenirlik katsayısı 0.79).

Belirtke tablosu kullanılarak Enerji Kaynakları ve Geri Dönüşüm konusu ile ilgili bilgileri ölçmeye yönelik 30 taslak başarı testi geliştirilmiştir. Testin kapsam geçerliğini sağlamada uzman görüşüne başvurulmuştur. Uzmanlar ölçekte yer alan her maddeyi Fen Bilimleri dersi öğretim programı kazanımları çerçevesinde "uygun", "uygun değil" ve "geliştirilmesi gerekir" şeklinde değerlendirmiş, uzmanların dönütleri doğrultusunda uzmanlar arasındaki tutarlılık sağlanarak ölçme aracının kapsam geçerliği sağlanmıştır. Test maddelerinin yapı geçerliliğinin sağlanması için alt üst grup ortalamaları farkına dayalı madde analizi ve korelasyona dayalı madde analizi yapılmıştır, Madde ayırıcılık gücü ve her bir maddenin çift serili korelasyon katsayı değeri 0.30'un altında olan maddeler testten çıkartılarak KR-20 güvenirlik katsayısı 0.85 olarak belirlenen 25 maddelik nihai test elde edilmiştir. Şekil 1'de başarı test maddelerinden biri yer almaktadır.

\begin{tabular}{|c|c|c|}
\hline & Enerji çeşidi & Kaynak veya Yakıtı \\
\hline I & Biyokütle & Biyolojik atık \\
\hline II & Jeotermal & Nehirler \\
\hline III & Nükleer & Radyoaktif Madde \\
\hline IV & Hidroelektrik & Yer altı Suları \\
\hline
\end{tabular}

17. Yukarıdaki tabloda yapılan yanlışı̆̆ı̆n düzeltilmesi için hangi enerji çeşitlerinin yerleri değiştirilmelidir?
A)I ve II
B) I ve III
C) II ve IV
D) II ve IV

Şekil 1. Başarl testinde yer alan soru örneği

Çalışmada kullanılan Fen Bilimleri dersine yönelik tutum ölçeğinde yer alan madde örnekleri Şekil 2'de, Fen öğrenme yaklaşımına yönelik tutum ölçeği madde örnekleri ise Şekil 3'de yer almaktadır. 


\section{FEN BILIMLERI DERSINE YÖNELIK TUTUM}

$\begin{array}{lll}\text { 1. } & \text { Fen ve Teknoloji dersine çalışrken canım sıkılıyor. } \\ \text { 2. } & \text { Fen ve Teknoloji dersi düşünce sistemimi geliştirmiyor. } \\ \text { 3. } & \text { Fen ve Teknoloji dersinde sıkılıyorum. } \\ \text { 4. } & \text { Fen dersi çevremizdeki doğal olayları anlamamı sağlıyor. } \\ \text { 5. } & \text { Fen ve Teknoloji dersi konularını anlamada zorlanıyorum. } \\ \text { 6. } & \text { Fen ve Teknoloji derslerine zevkle girerim. }\end{array}$

Şekil 2. Fen Bilimleri dersine yönelik tutum ölçeğinde yer alan madde örnekleri

\section{FEN ÖĞRENME YAKLASIMINA YÖNELIK TUTUM}

1.Fenle ilgili konular içeren dergi ve kitapları okumaktan zevk alııım.

2.Fen ve Teknoloji dersinde etkinlik yapmanın sıkıcı olduğunu düşünürüm.

3.Fen dersinde ödevlerin, projelerin oluşu beni sıkar.

4.Fen konuları ile ilgili internetten araştırma yapmak sıkıcıdır.

5.Fen derslerinde görsel öğelerin kullanılması (video, sunum gibi) öğrenmeyi kolaylaştırır.

Şekil 3. Fen öğrenme yaklaşımına yönelik tutum ölçeği madde örnekleri

\section{Uygulama Aşaması}

Deneysel çalışma sürecinde Enerji Kaynakları ve Geri Dönüşüm konusu; kontrol grubu öğrencileri ile öğretim programı ve öğretmen kılavuz kitabında yer alan etkinlikler çerçevesinde işlenmiștir. Deney grubu öğrencileri ile Jigsaw I (birleştirme) tekniğinin yer aldığı, araştırmacılar tarafından geliştirilen ders tasarımına uygun şekilde işlenmiştir. Altı ders saati olarak tasarlanan çalışmada öğrenciler beş ayrı kümede birlikte çalışmış, araştırma süresince sirasıyla şu uygulamalar gerçekleştirilmiştir.

- Öğrencilerin konuyla ilgili bilgi seviyelerini ve tutumlarını belirlemek amacıyla başarı testi ve tutum ölçekleri ön test olarak uygulanmıştır.

- Gereksiz enerji kullanımının etkilerine bağlı olarak ortaya çıkan Küresel İklim Değişikliğini anlatan kısa video izlettirilerek öğrencilerin enerjinin günlük hayatta yanlış kullanımını fark etmeleri sağlanmıştır.

- Enerji nedir? sorusuna yanıt alındıktan sonra, enerji nerelerde kullanılır? vb. bir soru ile beyin firtınası yöntemi kullanılmış, öğrencilerin enerjinin kullanım alanları konusundaki fikirleri, yorum yapılmaksızın tahtaya not edilmiştir.

- Yenilenebilir Enerji Kaynakları ve Yenilenemez Enerji Kaynakları kavramları hakkında öğrenci görüşleri alınmış, bu enerji kaynaklarının özellikleri, doğaya ve çevreye olan etkilerinin öğrenilmeye çalışılacağı ifade edilmiştir.

- Sandalyenin Hayat Döngüsü Etkinliği gerçekleştirilmiştir.

○ Öğretmen sandalyesi tahtanın ön kısmına getirilmiş, öğrencilerden bu sandalyenin elde ediliş sürecinde başından geçenleri düşünmeleri için öğrencilere 1 dakika süre verilmiştir.

- Sandalyede kullanılan malzemelerin neler olduğu sorulmuş, cevaplar tahtaya sırayla yazılmıştır. 
○ Her bir malzemenin, sandalyedeki son şekli verilinceye kadarki sürede başından geçen işlemler, gruplardan fikir alınarak tahtaya sıralanmıştır.

- Her malzeme için gerçekleştirilen uygulamalarda nerelerde enerji harcandığı ve çevreye atık verildiği renkli kalemle belirtilmiştir.

- Tahtada enerji harcanan kısımlara vurgu yapılarak, sadece bir sandalyenin elde edilmesi sürecinde bile ne kadar çok yerde enerji harcandığı ve dışarıya atık verildiğine dikkat çekilmiştir.

- Sandalyenin elde edilişinde harcanan enerjinin kaynağı olarak nelerin kullanılabileceği sorusu sorulmuş, öğrencilerden yanıtlar alındıktan sonra yenilenemez ve yenilenebilir enerji kaynaklarının neler olduğu konusuna geçiş yapılmıştır.

- Araştırmacılar tarafından hazırlanan Yenilenemez Enerji Kaynakları ve Yenilenebilir Enerji Kaynakları konularını içeren fasiküller öğrencilere dağıtılmıştır.

- Öğrencilere Yenilenemez ve Yenilenebilir Enerji Kaynakları Bölümlerinin Jigsaw I (birleştirme) tekniği ile çalışılacağı bilgisi verilmiştir.

- Jigsaw I (Birleştirme) tekniği uygulanmıştır.

- Her bir grupta yer alan öğrenciler birden beşe (ya da altıya kadar) numaralandırılmıştır.

- Her gruptaki aynı numaralı öğrencilerin bir kümeye gelmeleri sağlanmıştır.

- Yeni gruplara aşağıda belirtildiği şekilde konu paylaşımı yapılmıştır.

- Grup 1. Yenilenemez Enerji Kaynağı Nedir? Bu enerji kaynaklarının kullanım süresi ve doğaya olan etkileri

- Grup 2. Fosil Yakıtlar ve Nükleer Enerji Nedir? Özellikleri Nelerdir?

- Grup 3. Yenilenebilir Enerji Kaynağı Nedir? Bu Enerji Kaynağının Doğaya Olan Etkileri

- Grup 4. Hidroelektrik Enerjisi, Rüzgar Enerjisi, Güneş Enerjisi

- Grup 5. Jeotermal Enerji, Biyokütle

○ Öğrencilerden 5 dakika süresince kendilerine verilen bölümü bireysel okumaları, daha sonra grupta yer alan diğer öğrencilerle 15 dakika süresince tartışarak ilgili konu hakkında uzmanlaşmaları gerektiği bilgisi verilmiş ve süreç başlatılmıştır.

○ Uzmanlaşma sürecinde araştırmacı grupları dolaşarak, öğrencilerin anlamadıkları noktaları açıklamış, hatalı bilgi paylaşımı olan kısımlarda müdahalelerde bulunmuştur.

○ Süreç sonunda öğrenciler tekrar kendi masalarına geçmiş, her grup elemanı uzmanlaştığı konuyu grubundaki arkadaşlarına $5 \mathrm{dk}$ süre içerisinde anlatmıştır.

○ Anlatım işlemi tamamlandıktan sonra öğrencilerin grup olarak kendilerine verilen A3 kağıdına 15 dakika süre içerisinde enerji kaynakları ile ilgili birer poster hazırlamaları istenmiştir.

- Her grup, çalışmasını tamamladıktan sonra 5 dakika süre içerisinde tahtaya grupça kalkarak hazırladığı posteri arkadaşlarına sunmuştur.

- Geri dönüşümün önemini anlatan çizgi film izletilmiş, çizgi film kahramanlarının konuşmaları üzerinde tartışılmıştır.

- Öğrencilere ne tür malzemelerin geri dönüşümünün yapıldığı sorusu yöneltilmiş, öğrencilerden bireysel olarak defterlerine liste yazmaları istenmiştir.

- Tüm öğrenciler listesini tamamladıktan sonra gruplarındaki arkadaşlarıyla yazdıklarını karşılaştırmaları istenmiş ve gruplardan listelerini sınıfla paylaşmaları sağlanmıştır.

- Geri dönüşümün neden önemli olduğu konusunda grup üyelerinin konuşması istenmiş, grupların yanıtları alınarak tahtaya yazılmıştır.

- Tahtaya yazılan durumlarla ilgili grupların düşünceleri dinlenmiştir.

- Bizim Kasabamız Fuarı adlı etkinlik gerçekleştirilmiştir.

- Her gruba birer mimarlık şirketi olduğu ve her şirketin Büyükşehir Belediyesi tarafından düzenlenen fuarda aşağıda yer alan konuyla ilgili stant açacağı bilgisi verilmiştir. Fuar sonunda 5 şirketten birinin hazırladığı kasaba planını fuara katılan şirketler ve Belediye temsilcilerinin seçeceği konusunda da açıklama yapılmıştır.

- Gruplara yeni bir kasaba kurulacağı ve bu kasabada neler yer alacağı, kasabanın enerji ihtiyaçlarını ne şekilde karşılayabilecekleri, geri dönüşüm konusunda ne tür uygulamalar gerçekleştirecekleri ile ilgili bir plan hazırlamaları istendiği bilgisi verilmiştir.

- Grupların verilen A3 kağıdı ve renkli keçeli kalemleri kullanarak 30 dakika süre içerisinde planı hazırlamaları sağlanmıştır.

- Öğrencilere gruplar çalışmasını tamamladıktan sonra sınıfın 5 farklı köşesinde hazırladıkları planı sunmak üzere stant açacakları ve. 20 dakika boyunca stantların gezileceği açıklaması yapılmıştır.

○ 20 dakika boyunca her stant gezilmiş, stanttaki görevli öğrenciler hazırladıkları planı sunmuştur. 
○ Gruplar masalarına dönmüş, her grup 5 dakika içerisinde tartışarak, beğendikleri planı, beğenme sebeplerini nedenleri ile yazılı hale getirmiştir.

○ Her grubun sözcüsü seçtikleri planla ilgili düşüncelerini açıklamıştır.

- Araştırmacı kısa bir toparlama yapmış ve hazırlanan planlar bir hafta süresince sınıf panosunda sergilenmiştir.

- Ön test olarak uygulanan başarı testi ve tutum ölçekleri son test olarak uygulanmıştır.

\section{Verilerin Analizi}

Çalışmada "enerji kaynaklarl ve geri dönüşüm” konusu için geliştirilen tasarım uygulanan deney grubu ve 2005 yılı fen bilimleri dersi öğretim programı çerçevesinde ders işlenen kontrol grubu arasında başarı ve tutum düzeyleri açısından farklılık olup olmadığını tespit edebilmek için elde edilen veriler; SPSS 16 istatistik paket programına girilmiş, analizler gerçekleştirilmiştir. Bu çalışmada, jigsaw tekniğini de içeren işbirlikli öğrenme yönteminin öğrencilerin fen ve teknoloji dersi akademik başarısı, ders ve öğrenme yöntemlerine yönelik tutumlarına etkisi incelenmiştir. Cinsiyet, ön test tutum puanları ve başarı testi ön test puanı bağımsız değişkenleri kontrol edildiğinde, jigsaw tekniğini içeren işbirlikli öğrenme yönteminin başarı testi son test puanı, ders ve öğrenme yöntemlerine yönelik son test tutum puanı olmak üzere üç bağımlı değişkene etkisi MANCOVA ve devamında ANCOVA teknikleri ile analiz edilmiştir. Elde edilen sonuçlar 0.05 anlamlılık düzeyi göz önünde bulundurularak değerlendirilerek yorumlanmıştır.

Varyans analizinin bir uzantısı olan kovaryans analizi (Tabachnick ve Fidell, 2014), bir çalışmada etkisi öğrenilmeye çalışılan bir ya da iki bağımsız değişkenin dışında, bağımlı değişken ya da değişkenler ile ilişkisi bulunan ve ortak değişken (kovaryant) olarak adlandırılan bir başka değişkenin ya da değişkenlerin istatistiksel anlamda kontrolünü sağlayan bir yöntem olarak tanımlanabilir. (Büyüköztürk, 2010). Kovaryans analizinde dikkate alınan ortak değişken, aralık ya da oran ölçeğinde olmalıdır. Kovaryant seçimi yapılırken; ortak değişkenin her grup için bağımlı değişken üzerinde benzer etkiyi göstermesi (ortak değişken ile bağımlı değişken(ler) arasındaki ilişkinin türünün belirlenmesi), ortak değişken (ler)'in güvenilir olması, ortak değişkenler arasındaki korelasyonun belirli bir aralıkta olması gerekir (Kalayc1, 2008). Kovaryans analizi, ortak değişken etkilerinin kaldırılmak istendiği deneysel çalışmalarda kullanılır (ön test-son test araştırmaları). Ön test puanları bu tür çalışmalarda ortak değişken olarak kullanılır (Büyüköztürk, 2010).

Tek yönlü Mancova'da tek bir kategorik bağımsız değişsen ile bir ya da daha fazla ortak değişken ve birden fazla bağımlı değişken; İki yönlü Mancova' da ise iki kategorik bağımsız değişken ile bir ya da daha fazla ortak değişken ve birden fazla bağımlı değişken yer almaktadır (Cooley ve Lohnes, 1971). Bu çalışmada; araştırmanın amacı doğrultusunda iki yönlü Mancova kullanılmıştır.

\section{Bulgu ve Yorumlar}

Deneysel çalışma sürecinde ön test ve son test olarak uygulanan başarı testi ve tutum ölçeği puanları Şekil 4'de yer almaktadır. Şekil 4 incelendiğinde deney grubu öğrencilerinin üç ölçme aracı ön test puanlarının kontrol grubu öğrencilerinden daha yüksek olduğu gözlenmektedir.

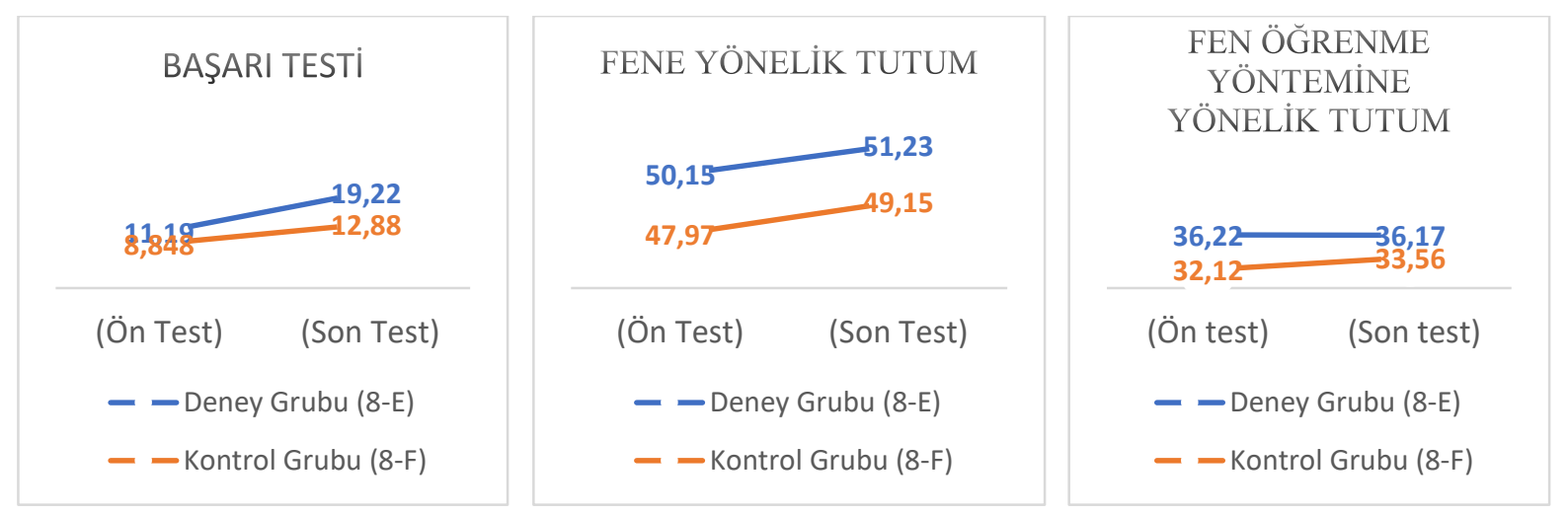

Şekil 4 Deney ve Kontrol Grubu Öğrencilerine Uygulanan Testlere Ait Veriler 
Deney ve kontrol gruplarının başarı ve tutum testlerinden elde ettikleri ortalama değerler, çarpıklık değerleri, standart sapmalar, basıklık değerleri, maksimum ve minimum değerler incelendiğinde elde edilen betimsel veriler Hata! Başvuru kaynağı bulunamadı.Tablo 4’de sunulmuştur.

Tablo 4.

Grupların Başarı Testi ve Tutum Ölçekleri İle İlgili Temel Tanımlayıcı İstatistikler

\begin{tabular}{|c|c|c|c|c|c|c|c|c|c|}
\hline & Test & Grup & $\mathbf{N}$ & $\bar{x}$ & SS & Çarpıklık & Basıklık & Varyans & Medyan \\
\hline \multirow[t]{4}{*}{$\mathrm{ABT}$} & Ön Test & $\mathrm{DG}$ & 37 & 11.19 & 3.37 & .081 & -.75 & 11.32 & 11.00 \\
\hline & & $\mathrm{KG}$ & 33 & 8.85 & 4.94 & .73 & -.69 & 24.45 & 7.00 \\
\hline & Son Test & DG & 37 & 19.22 & 3.59 & -.66 & -.14 & 12.90 & 20.00 \\
\hline & & $\mathrm{KG}$ & 33 & 12.88 & 4.95 & .42 & -.98 & 24.49 & 13.000 \\
\hline \multirow[t]{4}{*}{ FВyTÖ } & Ön Test & DG & 37 & 50.15 & 8.41 & .08 & -.53 & 70.71 & 50.00 \\
\hline & & $\mathrm{KG}$ & 33 & 47.97 & 6.70 & .52 & -.31 & 44.898 & 46.00 \\
\hline & Son Test & DG & 37 & 51.23 & 9.13 & -.23 & -.75 & 83.37 & 52.00 \\
\hline & & $\mathrm{KG}$ & 33 & 49.15 & 5.78 & -.09 & -.85 & 33.45 & 50.000 \\
\hline \multirow[t]{4}{*}{ FÖYyTÖ } & Ön Test & DG & 37 & 36.22 & 8.18 & .19 & -1.15 & 66.92 & 35.00 \\
\hline & & $\mathrm{KG}$ & 33 & 32.12 & 6.55 & .13 & -1.09 & 42.91 & 29.8 \\
\hline & Son Test & DG & 37 & 36.17 & 7.28 & -.22 & -.51 & 52.99 & 37.00 \\
\hline & & $\mathrm{KG}$ & 33 & 33.56 & 7.39 & -.53 & .62 & 54.62 & 34.00 \\
\hline
\end{tabular}

Tablo 4 incelendiğinde üç ölçme aracı için de deney grubu öğrencilerinin hem ön test puanları hem de son test puanları daha yüksektir. Verilerin normal dağılımı skewnes (çarpıklık) ve kurtosis (basıklık) değerlerine bakılarak incelenmiştir. George ve Mallery (2003) kurtosis değerlerinin +2 ve -2 aralığına bulunmasını normal dağılım için yeterli olduğunu ifade etmektedir. Tablolar incelendiğinde tüm verilere ait çarpıklık ve basıklık değerlerinin önerilen aralıkta bulunduğu görülmektedir.

Grup büyüklüğünün 50'den küçük olması durumunda puanların normalliğe uygunluğunu incelemede ShapiroWilks testinden de yararlanılır. Grupların akademik başarı testi ve tutum ölçeklerinden elde edilen verilerin normal dağılım gösterip göstermediğini belirlemek için Shapiro-Wilks normallik testi verileri de incelenmiştir.

Tablo 5.

Grupların Akademik Başarı ve Tutum Ölçekleri Ön Test-Son Test Shapiro-Wilks Normallik Testi Sonuçları

\begin{tabular}{|c|c|c|c|c|c|}
\hline \multirow{2}{*}{ Uygulanan Test } & & \multirow{2}{*}{ Grup } & \multicolumn{3}{|c|}{ Shapiro Wilks } \\
\hline & & & Statistic & df & $\mathbf{p}$ \\
\hline \multirow{4}{*}{$\mathrm{ABT}$} & Ön Test & DG & .98 & 37 & .56 \\
\hline & & $\mathrm{KG}$ & .90 & 33 & .00 \\
\hline & Son Test & DG & .94 & 37 & .05 \\
\hline & & $\mathrm{KG}$ & .93 & 33 & .05 \\
\hline \multirow[t]{4}{*}{ FByTÖ } & Ön Test & DG & .98 & 37 & .73 \\
\hline & & $\mathrm{KG}$ & .95 & 33 & .15 \\
\hline & Son Test & DG & .97 & 37 & .38 \\
\hline & & $\mathrm{KG}$ & .96 & 33 & .25 \\
\hline \multirow[t]{4}{*}{ FÖYyTÖ } & Ön Test & DG & .94 & 37 & .05 \\
\hline & & $\mathrm{KG}$ & .91 & 33 & .01 \\
\hline & Son Test & DG & .97 & 37 & .42 \\
\hline & & $\mathrm{KG}$ & .95 & 33 & .15 \\
\hline
\end{tabular}

Tablo 5 incelendiğinde; Shapiro-Wilks testinde hesaplanan p değerinin, $\alpha=.05$ 'ten büyük çıkması (KG'nin ABT son test ve FÖYyTÖ ön test sonuçları hariç), bu anlamlılık düzeyinde puanların normal dağılımdan anlamlı (aşırı) sapma göstermediğini ortaya koymaktadır (Büyüköztürk, 2010).

Çarpıklık ve basıklık değerlerinin önerilen aralıkta bulunması ve KG grubunun iki test haricinde grupların başarı testi ve tutum ölçekleri Shapiro Wilks testinde hesaplanan p değerlerinin $\alpha=.05$ 'ten büyük çıkması nedeniyle verilerin normal dağılım gösterdiği kabul edilmiş, parametrik testlerle analiz işlemleri gerçekleştirilmiştir.

Mancova analizine başlamadan önce eş değişkenler (covariates) belirlenmiştir. Daha önce belirtilen bağımlı ve bağımsız değişkenler arasındaki ilişki öncelikle incelenmiştir. Elde edilen veriler 
Tablo 6'da yer almaktadır.

Tablo 6.

Bă̆ımlı ve Bă̆ımsız Değiş̧kenler Arası İlişki (pearson correlation)

\begin{tabular}{lrrr}
\hline \multirow{2}{*}{ Değişkenler } & \multicolumn{3}{c}{ Korelasyon Katsayıları } \\
\cline { 2 - 4 } & ABT-S & FByT-S & FÖYyT-S \\
\hline Cinsiyet & -.25 & -.19 & -.24 \\
ABT-Ö & $.66^{* *}$ & .21 & .17 \\
FByT-Ö & $.37 * *$ & $.55^{* *}$ & $.39^{* *}$ \\
FÖYyT-Ö & .27 & $.47^{* *}$ & $.54^{* *}$ \\
\hline
\end{tabular}

**. Correlation is significant at the 0.01 level (2-tailed).

Tablo 6 incelendiğinde başlangıçta eş değişken olması düşünülen dört değişkenden cinsiyet dişındaki üç değişkenin de bağımlı değişkenle ilişkili olduğu gözlenmektedir. Bu nedenle bu üç değişken bundan sonraki analiz süreçlerinde eş değişken olarak analize alınmıştır.

MANCOVA uygulaması öncesinde bazı varsayımların sağlaması gerekmektedir. Bunlar verilerin normal dağılım göstermesi, regresyonun homojenliği (homogeneoity of regression), varyans eşitliği (equality of variances), çoklu doğrusalda eş değişken değerlerinin korelâsyonları (multicollinearity) ve son olarak da gözlem bağımsızlığı olarak sınıflanmıştır (Türksoy, 2012). Tablo 4'de yer alan çarpıklık-basıklık değerleri ve Tablo 5 incelendiğinde verilerin normal dağılım gösterdikleri gözlenmektedir. Bu nedenle normal dağılım şartı sağlanmıştır.

Kovaryans eşitliğini test etmek için Box's M 31.681 olarak hesaplanmış ve kovaryansların homojen olduğu saptanmıştır $[\mathrm{F}(18,6,703 \mathrm{E} 3)=1.593 ; \mathrm{p}>.05]$. Grupların elde edilen puanlarının varyansları eşit olmasını içeren varsayımın sağlanıp sağlanamadığını tespit etmek için Levene's Testi Hata Varyans Eşitliği araştırılmıştır. Elde edilen bulgular Tablo 7'de yer almaktadır. Tablo 7 incelendiğinde üç bağımlı değişken puanının anlamlılık düzeyi p>.005 olduğu için hata varyansı eşitlik analiz varsayımının sağlandığı görülmektedir.

Tablo 7.

Levene's Testi Hata Varyansı Eşitliği Sonuçları

\begin{tabular}{lrrrr}
\hline & F & df1 & df2 & p \\
\hline ABT-S & .73 & 3 & 66 & .538 \\
FByT-S & .96 & 3 & 66 & .418 \\
FÖYyT-S & 1.69 & 3 & 66 & .178 \\
\hline
\end{tabular}

Çok boyutluluk varsayımının sağlanıp sağlanmadığını belirlemek için eş değişkenlerin birbirleri ile olan ilişkileri incelenmiş ve elde edilen veriler Tablo 8 'de sunulmuştur. Bu varsayımın sağlanabilmesi için eş değişkenler arasındaki korelasyon katsayısının $0.8^{\text {ee }}$ in altında olması gerekmektedir (Türksoy, 2012). Üç değişken için de korelasyon değeri <0.8 olduğu için çok boyutluluk varsayımı sağlanmıştır.

Tablo 8.

Eş Değişkenlerin Birbiriyle İlişkisi

\begin{tabular}{lrrr} 
& ABT-Ö & FBYT-Ö & FÖYyT-Ö \\
\hline ABT-Ö & 1 & $.43^{* *}$ & $.35^{* *}$ \\
FBYT-Ö & $.43^{* *}$ & 1 & $.65^{* *}$ \\
FÖYyT-Ö & $.35^{* *}$ & $.65^{* *}$ & 1 \\
\hline
\end{tabular}

**. Correlation is significant at the 0.01 level (2-tailed). 
Öğrencilere verilen dönütler her aşamada araştırmacının gözleminde ve kontrolünde gerçekleştirilmiştir. Uygulamalar birbirinden bağımsız olarak yapılmış ve araştırmacı ortamla etkileşime girmemiştir. Bu nedenle bağımsızlık varsayımı da sağlanmıştır.

Deney ve kontrol grubunun ABT-S, FByT-S ve FÖYyT-S düzeltilmiş puanları

Tablo 9'da yer almaktadır. Tüm analizler bu düzeltilmiş ortalama puanlara göre gerçekleştirilmiştir.

Tablo 9.

Düzeltilmiş Ortalama Değerleri

\begin{tabular}{llrr}
\hline Bağımlı değişkenler & Yöntem & Ortalama & Düzeltilmiş Ortalama \\
\hline ABT-S & Deney & 19.22 & 18.53 \\
& Kontrol & 12.88 & 13.65 \\
FByT-S & Deney & 51.23 & 50.64 \\
& Kontrol & 49.15 & 50.02 \\
FÖYy-S & Deney & 36.17 & 35.48 \\
& Kontrol & 33.56 & 34.75 \\
\hline
\end{tabular}

MANCOVA için gerekli varsayımlar karşılandığı için analiz işlemlerine geçilmiş ve analizde elde edilen veriler Tablo 10Hata! Başvuru kaynağı bulunamadı.'da sunulmuştur. Çalışmanın bağımlı değişkenleri ABT-S, FByT$\mathrm{S}$ ve FÖYyT-S'dir. Bağımsız değişkenler ise yöntem, cinsiyet, ABT-Ö, FByT-Ö ve FÖYyT-Ö dür. Bağımsız değişkenlerden ABT-Ö, FBYT-Ö ve FÖYyT-Ö eş değişken olarak kullanılmıştır.

Tablo 10.

Deneysel Desen Etkisine Yönelik MANCOVA Analizi Sonuçları

\begin{tabular}{lrrrrrr}
\hline Bağımsız Değişkenler & Wilks' Lambda & F & Sd1 & Sd2 & sig & Eta kare \\
\hline Kesme Noktası &, 724 & 7.74 & 3.00 & 61.00 & .000 & .28 \\
Yöntem &, 647 & 11.09 & 3.00 & 61.00 & .000 & .35 \\
ABT-Ö &, 646 & 11.16 & 3.00 & 61.00 & .000 & .35 \\
FByT-Ö &, 848 & 3.64 & 3.00 & 61.00 & .017 & .15 \\
FÖYyT-Ö &, 835 & 4.03 & 3.00 & 61.00 & .011 & .17 \\
\hline
\end{tabular}

Tablodan, çalışmada kullanılan yöntemin bağımlı değişkenler üzerindeki varyansın \% 35 'ini açıkladığı görülmektedir. Ayrıca jigsaw tekniği ile öğretimin öğrencilerin ABT-S, FByT-S ve FÖYyT-S ortalama puanları üzerinde anlamlı bir etki oluşturduğu dikkat çekmektedir $(\lambda=0.65 \mathrm{p}=.000)$.

Yöntemin öğrencilerin ABT-S, FByT-S ve FÖYyT-S puanları üzerine ayrı ayrı etkilerini incelemek için ANCOVA analizi yapılmıştır. ANCOVA sonuçları Tablo 11'de sunulmuştur.

Tablo 11.

Deneysel Desen Değişkenleri İle İlgili ANCOVA Sonuçları

\begin{tabular}{llrrrrrr}
\hline Etki & $\begin{array}{l}\text { Bağımlı } \\
\text { Değişken }\end{array}$ & $\begin{array}{c}\text { Kareler } \\
\text { Toplamı }\end{array}$ & Sd & $\begin{array}{r}\text { Kareler } \\
\text { Ortalaması }\end{array}$ & F & $\begin{array}{r}\text { p } \\
\begin{array}{c}\text { Eta } \\
\text { Kare }\end{array}\end{array}$ \\
\hline Düzeltilmiş model & ABT-S & 1291.40 & 6 & 215.23 & 20.64 & $\mathbf{. 0 0 0}$ & .66 \\
& FByT-S & 1393.03 & 6 & 232.17 & 5.31 & $\mathbf{. 0 0 0}$ & .34 \\
& FÖYyT-S & 1217.22 & 6 & 202.87 & 4.99 & $\mathbf{. 0 0 0}$ & .32 \\
Kesme Noktası & ABT-S & 67,35 & 1 & 67.35 & 6.46 & .014 & .09
\end{tabular}




\begin{tabular}{|c|c|c|c|c|c|c|c|}
\hline Etki & $\begin{array}{l}\text { Bağımlı } \\
\text { Değişken }\end{array}$ & $\begin{array}{c}\text { Kareler } \\
\text { Toplamı }\end{array}$ & Sd & $\begin{array}{r}\text { Kareler } \\
\text { Ortalaması }\end{array}$ & $\mathbf{F}$ & $\mathbf{p}$ & $\begin{array}{r}\text { Eta } \\
\text { Kare }\end{array}$ \\
\hline & FByT-S & 852.32 & 1 & 852.32 & 19.50 & .000 & .24 \\
\hline & FÖYyT-S & 439.62 & 1 & 439.62 & 10.83 & .002 & .15 \\
\hline \multirow[t]{3}{*}{ Yöntem } & ABT-S & 343.95 & 1 & 343.95 & 32.98 & .000 & .34 \\
\hline & FByT-S & 5.45 & 1 & 5.45 & .13 & .725 & .00 \\
\hline & FÖYyT-S & 7.59 & 1 & 7.59 & .19 & .667 & .00 \\
\hline \multirow[t]{3}{*}{ Cinsiyet } & ABT-S & 10.91 & 1 & 10.91 & 1.05 & .310 & .02 \\
\hline & FByT-S & 30.58 & 1 & 30.58 & .69 & .406 & .01 \\
\hline & FÖYyT-S & 81.29 & 1 & 81.29 & 2.00 & .162 & .03 \\
\hline \multirow[t]{3}{*}{ ABT-Ö } & ABT-S & 310.78 & 1 & 310.78 & 29.80 & .000 & .32 \\
\hline & FByT-S & 19.61 & 1 & 19.61 & .45 & .505 & .01 \\
\hline & FÖYyT-S & 29.74 & 1 & 29.74 & .73 & .395 & .01 \\
\hline \multirow[t]{3}{*}{ FByT-Ö } & ABT-S & 30.73 & 1 & 30.73 & 2.95 & .091 & .05 \\
\hline & FByT-S & 431.42 & 1 & 431.42 & 9.87 & .003 & .14 \\
\hline & FÖYyT-S & 21.95 & 1 & 21.95 & .54 & .465 & .01 \\
\hline \multirow[t]{3}{*}{ FÖYyT-Ö } & ABT-S & 15.80 & 1 & 15.80 & 1.52 & .223 & .02 \\
\hline & FByT-S & 64.55 & 1 & 64.55 & 1.48 & .229 & .02 \\
\hline & FÖYyT-S & 406.01 & 1 & 406.01 & 10.00 & .002 & .14 \\
\hline \multirow[t]{3}{*}{ Hata } & ABT-S & 656.95 & 63 & 10.43 & & & \\
\hline & FByT-S & 2753.71 & 63 & 43.71 & & & \\
\hline & FÖYyT-S & 2557.20 & 63 & 40.59 & & & \\
\hline \multirow[t]{3}{*}{ Toplam } & ABT-S & 20384.00 & 70 & & & & \\
\hline & FByT-S & 180906.70 & 70 & & & & \\
\hline & FÖYyT-S & 89229.12 & 70 & & & & \\
\hline \multirow[t]{3}{*}{ Düzenli Toplam } & ABT-S & 1948.34 & 69 & & & & \\
\hline & FByT-S & 4146.74 & 69 & & & & \\
\hline & FÖYyT-S & 3774.42 & 69 & & & & \\
\hline
\end{tabular}

Tablo 11 incelendiğinde jigsaw tekniği içeren tasarımın ABT-S üzerinde anlamlı bir etki oluşturduğu görülmektedir $(\mathrm{F}(1,70)=32.98, \mathrm{p}=.000)$. Yöntem değişkeninin ABT-S bağımlı değişkeni üzerindeki etki büyüklüğünü test etmek için eta kare $\left(\eta^{2}\right)$ değeri incelendiğinde, yöntem bağımsız değişkeninin ABT-S üzerinde (eta kare, $\eta^{2}=.34$ ) geniş bir etkiye sahip olduğu, diğer bir ifadeyle jigsaw tekniği içeren tasarımın ABT-S üzerindeki varyansın yaklaşık \%34'ünü açıkladığı görülmektedir. ABT-Ö ve ABT-S testlerinden sonraki hesaplamalarda deney grubunda jigsaw tekniği içeren tasarımın öğrencilerin fen ve teknoloji dersindeki başarılarını artırmada etkili olduğu söylenebilir.

ABT-Ö puanının ABT-S puanı üzerinde anlamlı bir etkiye sahip olduğu yine Tablo 11'de dikkat çekmektedir $(\mathrm{F}(1,70)=29.80, \mathrm{p}=.000)$. ABT-Ö değişkeninin akademik başarı son testi üzerindeki etki büyüklüğü değeri incelendiğinde, ön test bağımsız değişkeninin son test üzerinde $\left(\eta^{2}=.32\right)$ geniş bir etkiye sahip olduğu görülmektedir. Bu durum, akademik başarı testi ön test uygulamasında başarılı olan öğrencilerin son testte aynı düzeyde başarı göstermelerine karşılık, başarı düzeyi düşük olan öğrencilerin nasıılsa başaramıyorum, yapamıyorum ya da anlayamıyorum gibi ön yargılara sahip olmasına bağlı olarak etkinliklere yeterince odaklanmamaları, sınav sorularını cevaplandırmak için yeterince çaba göstermemeleri gibi sebeplerle düşük performans sergilemelerinden kaynaklanabilir. Uygulama süresinin kısa olması diğer bir ifadeyle ön test ve son 
test uygulamaları arasındaki zamanın kısa olması da özellikle akademik başarısı düşük düzeydeki öğrencilerin kendilerini geliştirmek için yeterli çaba göstermemelerinin sebebi olabilir.

Başarı testi dışında tutum ölçeklerinin ön test puanlarının son test puanları üzerinde anlamlı etkiye sahip olduğu Tablo 11 'de gözlenmektedir. Fen Bilimlerine Yönelik Tutum ölçeği ön test- son test puanları için $F(1,70)=9.87$, p<.005 sonucu, Fen Öğrenme Yöntemlerine Yönelik Tutum Ölçeği ön test-son test puanları için de $\mathrm{F}(1,70)=10.00, \mathrm{p}<.005$ sonucu elde edilmiştir. Etki büyüklükleri incelendiğinde FByT-Ö-FByT-S için etki büyüklüğünün $\left(\eta^{2}=.14\right)$, FÖYyT-Ö-FÖYy-S için etki büyüklüğünün $\left(\eta^{2}=.14\right)$ olduğu dikkat çekmektedir. Her iki ölçek açısından da ön test puanları son test puanları üzerinde geniş bir etkiye sahiptir. Jigsaw tekniği ile öğretimin FByT-S ve FÖYyT-S üzerinde anlamlı bir etkiye sahip olmadığı yine Tablo 11'de gözlenmektedir (FByT-S için; F $(1,70)=.125, \mathrm{p}>.005$, FÖYyT-S için; F $(1,70)=.187$, p >.005). Ayrica Tablo 11'e göre cinsiyet değişkeni ABT-S, FByT-S ve FÖYyT-S üzerinde anlamlı bir etkiye sahip değildir.

\section{Tartışma ve Sonuç}

Betimsel istatistik sonuçları jigsaw tekniği ile öğretimin öğrencilerin akademik başarılarını arttırmada klasik yönteme göre daha etkili olduğunu gösterirken, fen bilimleri dersi ve fen öğretim yöntemlerine yönelik tutum puanlarının artışı açısından gruplar arasında benzerlik olduğunu ortaya koymaktadır.

MANCOVA sonuçları, ilköğretim 8. Sınıf öğrencilerinin ABT-Ö, FByT-Ö ve FÖYyt-Ö puanları kontrol edildiğinde, jigsaw tekniği ile öğretimin öğrencilerin ABT-S, FByT-S ve FÖYyT-S ortalama puanları üzerinde anlamlı bir etki oluşturduğunu göstermektedir $(\lambda=0.65 \mathrm{p}=.000)$. Ayrıca yapılan ANCOVA analiz sonuçları da 8 . sınıf öğrencilerinin ABT-Ö, FByT-Ö ve FÖYyT-Ö puanları kontrol edildiğinde, jigsaw tekniği ile öğretimin öğrencilerin başarı testi puanları üzerinde anlamlı bir etkisi bulunduğunu göstermektedir $(F(1,70)=32,984$, $\mathrm{P}=.000$ ). Literatür incelendiğinde araştırmada elde edilen bu sonuçlarla paralellik gösteren birçok çalışma olduğu gözlenmektedir. Dori, Yaroslavsky ve Lazarowitz (1995) hücre konusu öğretiminde jigsaw yöntemi ile geleneksel öğretim yönteminin öğrencilerin akademik başarıları, laboratuvar becerileri ve öğrenme faaliyetleri üzerindeki etkisini araştırmıştır. Çalışma sonucunda jigsaw yöntemi uygulanan deney grubu öğrencilerinin akademik başarılarının kontrol grubu öğrencilerine göre daha fazla olduğunu tespit etmiştir. Atasoy ve diğerleri (2007) öğrencilerin fiziksel ve kimyasal değişmeler konusunda birçok yanlış kavramaya sahip olduklarını tespit ettikleri çalışmalarında jigsaw tekniğini de içeren işbirlikli öğrenme yönteminin bu yanlış kavramaların azaltılmasında geleneksel öğretim yöntemine göre daha etkili olduğu sonucunu ulaşmıştır. Doymuş ve Şimşek (2007) üniversite birinci sınıf öğrencilerine kimyasal bağlar konusunun öğretiminde uyguladıkları jigsaw tekniğinin öğrencilerin akademik başarılarını artırdığı sonucuna ulaşmıştır. Souvignier ve Kronenberger (2007) ilkokul 3.sınıf öğrencileri ile astronomi ünitesi öğretiminde jigsaw tekniğini kullanmıştır. Araştırmacılar çalışma sonucunda tekniğin öğrencilerin akademik başarılarının artmasında etkili olduğu sonucuna ulaşmıştır. Doymuş (2008) üniversite 1. sınıf öğrencilerinin kimyasal denge konusunu anlamaları üzerine Jigsaw tekniğinin etkisini araştırdığı çalışması sonucunda Jigsaw tekniği uygulanan grubun geleneksel öğretim yöntemi uygulanan gruptan istatistiksel olarak anlamlı düzeyde daha başarılı olduğunu tespit etmiştir. Doğan, Uygur, Doymuş ve Karaçöp (2010) işbirlikli öğrenme yöntemi jigsaw tekniğinin ilköğretim 7. sınıf öğrencilerinin fen ve teknoloji dersi kuvvet ve hareket ünitesindeki başarılarına etkisini araştırdıkları çalışma sonucunda deney grubundaki öğrencilerin kontrol grubu öğrencilerine göre daha başarılı olduklarını belirlemiştir. Özdilek, Erkol, Doğan, Doymuş ve Karaçöp (2010) jigsaw tekniğinin 7.sınıf Fen ve Teknoloji dersi yaşamımızdaki elektrik ünitesindeki başarılarına etkisini araştırdıkları çalışmada jigsaw tekniğinin öğrencilerin akademik başarılarının artırılmasında olumlu ve belirgin bir etki ortaya koyduğu sonucuna ulaşmıştır. Yıldırım ve Girgin (2012) Jigsaw tekniğinin kullanılmasının 8. sınıf öğrencilerinin genetik ünitesindeki akademik başarı ve bilgi kalıcılığına etkisini araştırdıkları çalışmaları sonucunda Jigsaw tekniğinin öğrencilerin akademik başarıları üzerinde olumlu etkisi olduğunu ortaya koymuştur. Turaçoğlu, Alpat ve Ellez (2013), Jigsaw tekniğinin kimyasal bileşiklerin adlandırılması konusu öğretiminde etkilerini araştırdıkları çalışma sonucunda, Jigsaw tekniği uygulanan öğrencilerin akademik başarıları açısından istatistiksel olarak anlamlı bir fark olduğunu tespit etmiş̧tir. Doğan, Uçar ve Şimşek (2015) 6.sınıf Fen ve Teknoloji dersi yer kabuğu nelerden oluşur konusunun öğretiminde Jigsaw tekniğinin etkilerini araştırmış ve tekniğin akademik başarının artmasında etkili olduğu sonucuna ulaşmıştır. Kılınç ve Güven (2015) çalışmalarında ilköğretim 8. sınıf asitler ve bazlar ünitesinin öğretiminde Jigsaw tekniği kullanımının öğrencilerin akademik başarılarını artırdığı sonucuna ulaşmıştır. Ural, Ercan ve Gençoğlan (2017) 6.sınıf Kuvvet ve Hareket ünitesinin öğretiminde jigsaw tekniğinden yararlanmıştır. Jigsaw tekniği uygulanan deney grubu öğrencilerinin geleneksel yöntem uygulanan kontrol grubundan daha başarılı olduğu sonuca ulaşmıştır. Bununla birlikte Arslan (2012) ve 
Maden (2011) gibi araştırmacılar jigsaw tekniği uygulanan deney grubu öğrencileri ile kontrol grubu öğrencileri arasında benzerlik olduğunu ortaya koymuştur.

Jigsaw tekniğiyle öğretim uygulanan grubun daha başarılı olması, yukarıda açıklanan araştırmalarda da belirtildiği gibi öğrencilerin ortak bir hedef için hareket etmeleri, süreç içerisinde iletişimlerinin gelişerek diyaloglarının artması, birbirlerine daha fazla yardımcı olmaları, gruba dahil olarak ortak bir hedef için çaba harcamalarından ve grup hedefi için öğrenciye bireysel olarak sorumluluk düşmesinden kaynaklanabilir. Ayrıca Lord (2001)'un da ifade ettiği gibi işbirlikli öğrenme ortamlarında öğrenciler konuyla ilgili daha fazla konuşma, soru sorma, birbirlerine yardım etme firsatı buldukları, süreç içerisinde anlatıcı ve dinleyen rolünü dönüşümlü üstlendikleri ve dinleyici olduklarında anlatılanı dinlerken zihinlerindeki bilgiyi test etme ve kafasına takılan sorunun yanıtını akranlarıyla keşfetme şansı yakaladıkları için jigsaw tekniği uygulanan gruptaki öğrenciler, kontrol grubundaki öğrencilere göre daha başarılı olmuştur.

ANCOVA sonuçları, 8. Sınıf öğrencilerinin ABT-Ö, FByT-Ö ve FÖYyT-Ö puanları kontrol edildiğinde, jigsaw tekniği ile öğretimin öğrencilerin fen bilimleri dersi $(F(1,70)=.125, p>.005)$ ve fen öğretim yöntemlerine $F(1,70)$ $=.187, \mathrm{p}>.005)$ yönelik tutum puanları üzerinde etkisi olmadığını göstermektedir. Altıparmak ve Nakiboğlu (2005), yaptıkları çalışmada öğrencilerin laboratuvara yönelik tutum ve başarılarını değerlendirmek için Jigsaw-I tekniğinden yararlanmıştır. Çalışmanın sonucunda öğrencilerin akademik başarılarının arttığı ancak laboratuvara yönelik tutumlarında herhangi bir değişim gözlenmediğini rapor etmişlerdir. Bahadır (2011)'ın maddenin halleri ve 1Sı konusunda jigsaw tekniğini uygulayarak yürütttüğü çalışmada elde ettiği, tekniğin öğrencilerin fen ve teknolojiye yönelik tutumlarında anlamlı bir değişiklik görülmediği sonucu, bu çalışma ile örtüşmektedir. Ural, Ercan ve Gençoğlan (2017) da benzer sonuç elde etmiştir. Bu çalışmanın aksine literatürde Jigsaw tekniğinin öğrencilerin tutumlarını olumlu yönde etkilediğini belirten çalışmalar da mevcuttur. Eilks (2005) kimya dersi atomun yapısı konusu işlenirken uygulanan jigsaw tekniğinin öğrencilerin fene yönelik tutumları üzerinde etkili olduğu sonucuna ulaşmıştır. Uyar Kılıç (2017), insan ve çevre ünitesinin öğretiminde Jigsaw-I tekniğinden yararlanmış ve öğrencilerin akademik başarıları ile çevreye yönelik tutumlarındaki değişimi incelemiştir. Elde edilen sonuçlara göre öğrencilerin çevreye yönelik tutumlarında anlamlı bir değişimin gözlendiği rapor edilmiştir. Ayna (2009) da maddenin tanecikli yapısı konusunda yürüttüğü çalışmada öğrencilerin fen ve teknoloji dersine yönelik tutumlarında anlamlı bir değişim olduğunu belirlemiştir. Ayrıca Shabaan (2006) ve Şahin (2010) bu çalışmada elde edilen sonucun aksine jigsaw tekniğinin öğrencilerin motivasyonları üzerinde etkili olduğunu ortaya koymuştur.

\section{Öneriler}

1. Benzer çalışma Fen Bilimleri dersinin diğer sınıf seviyeleri ve üniteleri için yürütülebilir ve sonuçlar karşılaştırılabilir.

2. Çalı̧̧ma öncesinde, planlanan süreç ve teknik konusunda öğrenciler bilgilendirilmelidir.

3. Uygulama yapacak kişinin jigsaw tekniğinin olumlu ve olumsuzlukları konusunda yeterince bilgi sahibi olması önemlidir. Uygulama yapacak kişi süreç içerisinde olumsuz bir durumla karşılaştı̆̆ında ne tür tepkiler ortaya koyması gerektiğini önceden planlamalıdır.

4. Gruplar oluşturulurken, grupların karma olmalarına özen gösterilmelidir. Her grupta maksimum beş öğrenci yer almalıdır.

5. Grup oluştururken öğrencilerin fikirleri de dikkate alınmalıdır.

6. Uygulama sırasında işbirlikli öğrenme yöntemi Jigsaw tekniğinin daha etkin uygulanabilmesi için öğretmenin yaptığı yönlendirmelerin oldukça önem taşıdığı gözlenmiş̧tir. Bu nedenle uygulama sürecinde öğretmen gruplar arasında dolaşarak süreci izleyerek, gerekli olduğunda öğrencilere rehberlik etmelidir.

7. Bu çalışma sınırlı sayıda öğrenciyle gerçekleştirilmiştir. Bu konuda daha geniş çapta çalışmalar yapilmalidır.

\section{Kaynakça}

Açıkgöz Ün, K. (2008). Aktif öğrenme. İstanbul: Biliş Gelişimin Coşkusu.

Akar, M. S. ve Doymuş, K. (2015). Birlikte öğrenme ve öğrenci takımları başarı bölümlerinin fen bilimleri dersinde akademik başarıya etkisi (Kars il örneği). Kafkas Eğitim Araştırmaları Dergisi, 2 (3), 79-87. 
Akınoğlu, O. (2007). Öğretim kuram ve modelleri. Tan Şeref (ed.), Öğretim ilke ve yöntemleri, (s:123-166). Ankara: Pegema Yayıncılık

Altıparmak, M ve Nakiboğlu, M. (2005). Lise Biyoloji Laboratuvarlarında "İş Birlikli Öğrenme" Yönteminin Tutum ve Başarıya Etkisi. Türk Ĕgitim Bilimleri Dergisi, 3 (1), 105-123.

Arslan, A. (2012). Sözcük türleri öğretiminde Jigsaw tekniğinin etkisi. Dumlupınar Üniversitesi Sosyal Bilimler Dergisi, 1(32), 157-168.

Atasoy, B., Genç, E., Kadayıfçı, H. ve Akkuş, H. (2007). 7. sınıf öğrencilerinin fiziksel ve kimyasal değişmeler konusunu anlamalarında işbirlikli öğrenmenin etkisi. Hacettepe Üniversitesi Eğitim Fakültesi Dergisi, $32(1), 12-21$.

Aydın, B. (2014). Proceedings of the 2014 International Conference and Utility Exhibition on Green Energy for Sustainable Development (ICUE), 1-7.

Aymen Peker, E. (2018). 5. sınıf "canlılar dünyasını gezelim ve tanıyalım" ünitesinin klasik eğitsel oyunlar ve teknoloji destekli eğitsel oyunlarla ögretiminin değerlendirilmesi, Ondokuz Mayıs Üniversitesi, Eğitim Bilimleri Enstitüsü, Samsun.

Ayna, C. (2009). Fen ve Teknoloji dersinde Birleştirme II (Jigsaw II) Yönteminin kullanılmasının ve sosyoekonomik düzeyin ögrencilerin akademik başarı, Fen ve Teknoloji dersine yönelik tutum ve motivasyon düzeylerine etkisi. Yüksek Lisans Tezi, Zonguldak Karaelmas Üniversitesi, Sosyal Blimler Enstitüsü, Zonguldak.

Bahadır, E. (2011). Illköğretim 8. sınıf “Maddenin halleri ve ısı ünitesi” nin öğretiminde işbirlikli ögrenme temelli bilimsel mektupların kullanılmasının ögrencilerin tutum, başarı ve bilimsel-okuryazarlıklarına etkisinin incelenmesi. Yüksek Lisans Tezi, Erzincan Üniversitesi, Eğitim Bilimleri Enstitüsü, Erzincan.

Bayraç, H. N. ve Çıldır, M. (2017). AB yenilenebilir enerji politikalarının ekonomik büyüme üzerindeki etkisi. Uluslararası Yönetim İktisat ve İşletme Dergisi, 13(5), 201-212.

Berger, R. \& Hazne, M. (2005). The jigsaw method in the upper secondary school physics- Its 1mpact on motivation, learning and achievement. Proceeding of the Fifth International Conference of ESERA. Barcelona.

Bilgin, İ. ve Karaduman, A. (2005). İşbirlikli öğrenmenin 8. sınıf öğrencilerinin fen dersine karşı tutumlarına etkisinin incelenmesi. Ilkögretim-Online, 4(2), 32-45.

Büyüköztürk, Ş (2011). Deneysel Desenler, Öntest-Sontest Kontrol Grubu Desen ve Veri Analizi. (3. bask1), Ankara: PegemA Yayıncılık.

Büyüköztürk, Ş. (2010). Sosyal Bilimler için veri analizi el kitabı (12. bs.) Ankara: Pegem Akademi.

Carpenter, S. R. (2003). Incorporation of a cooperative learning technique in organic chemistry. Journal of Chemical Education, 80, 330-332.

Cohen, L., Manion, L., Marrison, K. (2007). Research methods in education. (6.edition), London: Routledge \& Falmer Yayıncilik.

Cooley, W. W. \& Lohnes, P. R. (1971). Multivariate data analysis. J. Wiley.

Çakırlar, E. (2015). Ortaöğretim öğrencilerinin yenilenebilir enerji kaynakları konusundaki farkındalık düzeylerinin belirlenmesi. Yayımlanmamış Yüksek Lisans Tezi, Hacettepe Üniversitesi, Eğitim Bilimleri Enstitüsü, Ankara. 
Çınar, S. ve Yılmazer, M. (2015). Yenilenebilir enerji kaynaklarının belirleyicileri ve ekonomik büyüme ilişskisi: Gelişmekte olan ülkeler örneği. Dokuz Eylül Üniversitesi İktisadi ve İdari Bilimler Fakültesi Dergisi, $30(1)$.

De Paz, T. (2001). The effectiveness of the jigsaw cooperative learning on students' achievement and attitudes toward science. Science Education International, 12 (4), 6-11.

Demirtaş, F. (2008). İşbirlikli öğrenmede birleştirme I tekniğinin ilköğretim beşinci sınıf öğrencilerinin fen ve teknoloji dersine ilişkin tutumların etkisi. Yüksek Lisans Tezi, Abant İzzet Baysal Üniversitesi, Sosyal Bilimler Enstitüsü, Bolu.

Doğan, A., Uygur, E., Doymuş, K. ve Karaçöp, A. (2010). İlköğretim 7. sınıf Fen ve Teknoloji dersinde Jigsaw tekniğinin uygulanması ve bu teknik hakkındaki öğrenci görüşleri. Erzincan Ĕ̆itim Fakültesi Dergisi, 12(1); 75-90.

Doğan, A., Uçar, S. ve Şimşek, Ü. (2015). Jigsaw tekniğinin 6. Sınıf fen ve teknoloji dersi “yer kabuğu nelerden oluşur?” Ünitesinin öğretiminde öğrenci başarısına etkisi. Mustafa Kemal Üniversitesi Sosyal Bilimler Enstitüsü Dergisi, 12(32), 416-432.

Doğru, M., \& Ünlü, S. (2012). Jigsaw IV tekniği kullanımının fen öğretiminde öğrencilerin motivasyon, fen kaygısı ve akademik başarılarına etkisi. Mediterranean Journal of Humanities, 11(2), 57-66. http://mjh.akdeniz.edu.tr/_dinamik/201/401.pdf adresinden erişilmiştir.

Dori, Y. J., Yaroslavsky, O. and Lazarowitz, R. (1995). The effect of teaching the cell topic using the jigsaw method on students' achievement and learning activity, ERIC clearinghouse for science. Mathematics and Environmental Education. Columbus, Ohio. ED, 387, 336.

Doymuş, K. (2008). Teaching chemical equilibrium with the jigsaw technique. Research in Science Education, 38 (2), 249-260.

Doymuş, K., \& Doğan, A. (2013). İşbirlikli öğrenme yöntemi. S. Büyükalan Filiz (Ed.), Öğrenme Öğretme Kuram ve Yaklaşımları, (s. 147-163). Ankara: Pegem Akademi.

Doymuş, K. ve Şimşek, Ü. (2007). Kimyasal bağların öğretilmesinde jigsaw tekniğinin etkisi ve bu teknik hakkında öğrenci görüşleri. Milli Eğitim Dergisi, 173 (1), 231-243.

Eilks, I. (2005). Experiences and reflections about teaching atomic structure in a jigsaw classroom in lower secondary school chemistry lesson. Journal of Chemical Education, 82, 313-319.

George, D. \& Mallery, P. (2003) SPSS for Windows Step by Step: A Simple Guide and Reference. 11.0 Update. 4th Edition. Boston: Allyn \& Bacon.

Gezer, E. H. (2013). Yenilenebilir enerji kaynaklarl ve Türkiye. Yüksek Lisans Tezi. Gazi Üniversitesi. Sosyal Bilimler Enstitüsü, Ankara.

Ghaith, G. \& El-Malak, M. A. (2004). Effect of jigsaw ii on literal and higher order EFL reading comprehension. Educational Research and Evaluation, 10(2), 105-115

Gillies, R. M. \& Boyle, M. (2010). Teachers' reflections on cooperative learning: issues of implementation. Teaching and teacher Education, 26 (4), 933-940.

Gürdal, A. (1988). Fen öğretimi. Deniz Kuvvetleri Komutanlı̆̆ı Yayınları, 21, 34-49.

Hedeen, T. (2003). The reverse jigsaw. A process of cooperative learning and discussion. Teaching Sociology, 31 (3), 325-332. 
Kalaycı, Ş. (2008). SPSS Uygulamalı çok değişkenli istatistik teknikleri. (3. Baskı). Ankara: Asil Yayın Dağıtım

Karasar, N. (2011). Bilimsel Araştırma Yöntemi. (22. Baskı). Ankara: Nobel Yayıncılık

Keser, O.F., Özmen, H. \& Akdeniz, F. (2003). Energy, environment and education relationship in developing countries' policies: A case study for Turkey. Energy Sources, 25 (2); 123-133.

Kılıç, M. A. (2013). Jigsaw tekniğinin 6. sınıf Fen ve Teknoloji dersi maddenin tanecikli yapısı ünitesinin ögretiminde ögrenci başarısına etkisi. Yayınlanmamış yüksek lisans tezi. Gazi Üniversitesi Eğitim Bilimleri Enstitüsü, Ankara.

Kılıçarslan, M., Aymen Peker, E. ve Gün, F. (2011). Yenilenebilir enerji kaynaklarının çevreye olan katkısına ilişkin ilköğretim öğrenci görüşleri: Samsun ili örneği. Samsun Sempozyumu, Samsun, 13-16 Ekim.

Kılınç, A. ve Güven, Y. E. (2015). Jigsaw tekniğinin öğrencilerin akademik başarısı ve bilgilerinin kalıcılığına etkisi. The Journal of Academic Social Science Studies, 37, 421-431.

Koç, E. ve Şenel, M. C. (2013). Dünyada ve Türkiye'de enerji durumu-genel değerlendirme. Mühendis ve Makina, 54(639), 32-44.

Köse, S., Şahin, A., Ergü, A., \& Gezer, K. (2010). The Effects of Cooperatıve Learnıng Experience on Eıghth Grade Students' achievement and Attıtude Toward Science. Education, 131(1), 169-180.

Lars Broman \& Aadu Ott., (1988). Solar education: the way forward. Sun Work Eur, 6:24-5.

Lord, R. T. (2001). Reasons for using cooperative learning in Biology teaching. The American Biology Teacher. 63 (1), 30-38.

Maden, S. (2011). Effect of jigsaw 1 technique on achievement in written expression skill. Educational sciences: Theory and Practice, 11(2), 911-917.

Mark, E. S., Volk, G. L. \& Hinckley, C. C. (1991). Cooperative learning in the undergraduate laboratory. Journal of Chemical Education, 68(5), 413-415.

Millî Eğitim Bakanlığı (MEB). (2013). Illköğretim kurumları (ilkokullar ve ortaokullar) fen bilimleri dersi (3,4,5,6,7 ve 8. Sınıflar) öğretim programı. Ankara: MEB Talim ve Terbiye Kurulu Başkanlığı.

Milli Eğitim Bakanlığı (MEB). (2018). Fen Bilimleri dersi (İlkokul ve Ortaokul 3,4,5,6,7 ve 8. Sınıflar) öğretim programı. Ankara: MEB Talim ve Terbiye Kurulu Başkanlığı.

Millî Eğitim Bakanlığı (MEB). (2014). Ortä̈ğretim 9. sınıf fizik ders kitabı. Ankara: Mili Eğitim Bakanlığ1 Yayınlar1.

Moreno, R. (2009). Constructing knowledge with an agent-based instructional program: a comparison of cooperative and individual meaning making. Learning and Instruction, 19, 433-444.

Özdilek, K., Erkol, M., Doğan, A., Doymuş, K. ve Karaçöp, A. (2010). Fen ve teknoloji dersinin öğretiminde jigsaw tekniğinin etkisi ve bu teknik hakkındaki öğrenci görüşleri. Erzincan Üniversitesi Eğitim Fakültesi Dergisi, 12(2), 209-224.

Plano Clark, V. L., \& Creswell, J. W. (2015). Understanding research: A consumer's guide. Upper Saddle River, NJ: Pearson Education.

Sanc1, M. (2011). Illkögrretim 4.sınıf fen ve teknoloji dersi ögretiminde uygulanan jigsaw ve grup araştırması tekniklerinin ögrencilerin akademik başarıları üzerine etkisi. Yayınlanmamış Yüksek Lisans Tezi. Atatürk Üniversitesi Eğitim Bilimleri Enstitüsü, Erzurum. 
Senemoğlu, N. (2004). Gelişim öğrenme ve ögretim: Kuramdan uygulamaya. Ankara: Gazi Kitabevi.

Shabaan, K. (2006). An initial study of the effects of cooperative learning on reading comprehension, vocabulary acquisition, and motivation to read. Reading Psychology, 27(5), 377-403.

Slavin, R. E. (2014). Cooperative learning and academic achievement: why does groupwork work?. Anales de psicología, 30 (3), 785-791.

Souvignier, E. \& Kronenberger, J. (2007). Cooperative learning in third graders' jigsaw groups for mathematics and science with and without questioning training. British Journal of Educational Psychology, 77, 755771 .

Student, D. (2015). Effects of Jigsaw Co-Operatıve Teachıng/Learnıng Strategy and School Locatıon on Students Achievement and Attıtude Towards Biology in Secondary School in Delta State . International Journal of Education and Research, 3(8). 31-40.

Surian, A., \& Damini, M. (2014). Becoming a cooperative learner-teacher. Anales de psicología, 30 (3), 808817.

Şahin, A. (2010). Effects of jigsaw II technique on academic achievement and attitudes to written expression course. Educational Research and Reviews, 5(12), 777-787.

Tabachnick, B. G. \& Fidell, L. S. (2014). Using multivariate statistics. London: Pearson

Tamah, S. T. (2007). Jigsaw technique in reading class of young learners: Revealing students' interaction. Journal of Language Teaching and Research, 7(2),187-198. http://files.eric.ed.gov/fulltext/ED495487.pdf sayfasından erişilmiştir.

Tran, V. D. \& Lewis, R. (2012). The effects of jigsaw learning on students' attitudes in a vietnamese higher education classroom. International Journal of Higher Education, 1(2), 9-20.

Tran, V. D. (2016). The effects of jigsaw learning on students knowledge retention in Vietnamese higher education. International Journal of Higher Education, 5 (2), 236-253.

Turaçoğlu, İ., Alpat, Ş. ve Ellez, M. A. (2013). Kimyasal bileşiklerin adlandırılması konusunun öğretilmesinde jigsaw tekniğinin etkileri. Eğitim ve Bilim, 38(167).

Türksoy, E. (2012). İlkögrretim 5. Sinıf fen ve teknoloji dersinde aktif ögrenme teknikleri ile zenginleştirilmiş ögretimin ögrencinin akademik başarıları ve tutumları üzerine etkisi. Yüksek Lisans Tezi, Mehmet Akif Ersoy Üniversitesi, Sosyal Bilimler Enstitüsü İlköğretim Anabilim Dalı, Mersin.

Uçar, S. (2014). Jigsaw tekniğinin 6.sınıf fen ve teknoloji dersi “yer kabuğu nelerden oluşur?” ünitesinin ögretimginde öğrenci başarısına etkisi. Yüksek Lisans Tezi, Gazi Üniversitesi Eğitim Bilimleri Enstitüsü, Ankara.

Ural, E., Ercan, O. \& Gençoğlan, D. M. (2017). The effect of jigsaw technique on 6th graders' learning of force and motion unit and their science attitudes and motivation. Asia-Pacific Forum on Science Learning and Teaching, 18 (1), 1-21.

Uyar Kılıç, E. (2017). Ortaokul fen bilimleri dersinde Jigsaw I ve kavram haritası destekli jigsaw I tekniği kullanmanın başarı, tutum ve kalıcılık üzerine etkisi. Doktora Tezi. Gazi Üniversitesi Eğitim Bilimleri Enstitüsü, Ankara.

Verbruggen, A., Fischedick, M., Moomaw, W., Weir, T., Nadaï, A., Nilsson, L. J., \& Sathaye, J. (2010). Renewable energy costs, potentials, barriers: Conceptual issues. Energy policy, 38(2), 850-861. 
Zacharia, C. Z., Xenofontes, A. N. \& Manoli, C. C. (2010). The effect of two different cooperative approaches on students' learning and practices within the context of a web quest science investigation. Educational Technology Research and Development, 59, 399-424.

\section{EXTENDED ABSTRACT}

The rapid increase in the world population, industrialization, technological developments and the increase in consumption every passing day constitute an intensive energy need. The reserve of energy resources such as oil and natural gas, which is one of the main energy sources, is rapidly depleted. Carbon dioxide and similar greenhouse gases are formed using these fuels. These gases cause global climate change. Therefore, today, renewable energy sources. are alternative sources of these fuels. Considering the importance of renewable energy sources for today and the future; education is of great importance in raising public awareness and encouraging the use of renewable energy resources.

In the science curriculum, the research-inquiry-based learning approach was taken as the basis for the students' active participation in the teaching activities. In this curriculum, emphasis was given to collaborative learning environments. When the literature is examined, it is seen that there are many cooperative learning methods. The jigsaw technique, which is the subject of this study, was developed by Elliot Aronson and aims to improve the cooperation between the students and to enable the students to communicate with each other by removing the competitive environment.

The aim of this study is to investigate the effect of using jigsaw technique on teaching of "Energy Source and Recycle" which is included in science curriculum, on the students' academic achievements, attitudes towards science lesson and attitudes towards science learning methods. In the study, semi-experimental design which is one of the quantitative research methods and which is based on pre-test-post-test application for unequal groups was used.

This study had been performed with the participation of a total of 70 eighth-grade students ( 28 girls and 42 boys) in two different groups of a secondary school that is located in Samsun in the academic year 2014-2015. One of these groups was experimental group $(n=37)$ that was applied jigsaw technique used in the implementation of cooperative learning and the other one was control group $(n=33)$ that was applied traditional method.

The data collection instruments which were used in the study is Academic Achievement Test (AAT), Attitude towards Physical Sciences Scale (AtPSS), Attitude towards Science Learning Approach (AtSLA). The data were analyzed with MANCOVA and ANCOVA techniques.

The results of correlation analysis had showed that there is an significant relationship between scores ABT-A and ABT-B; between scores AtPSS-B and ABT-A; between scores AtPSS-B and AtPSS-A; between scores AtPSS-B and AtSLA-A; between scores AtSLA-B and AtSLA-A; between AtSLA-B and AtPSS-A. ANCOVA results had shown that when the ABT-B, AtPSS-B and AtSLA-B scores were controlled, teaching with jigsaw technique had a significant effect on students' achievement test scores but not on attitude scores. It was also found that the variable gender had no significant effect on ABT-A, AtPSS-B and AtSLA-B. It was determined that jigsaw technique had a positive effect on students' academic achievement and that pre-test scores of attitude scales had a significant effect on post-test scores but did not have a significant effect on the post-test of science course and attitude towards science learning approaches.

Based on these findings, following recommendations can be made: Before the study, students should be informed about the planned process and technique. It is important to have enough knowledge about the positive and negative aspects of the jigsaw technique. The person who will be practicing should plan what kind of reactions should be put into effect when faced with a negative situation in the process. When creating groups, care must be taken to ensure that groups are mixed. In each group, a maximum of five students should take place. In the process of implementation, the teacher should follow the process by moving between the groups and should guide the students when necessary. 